\title{
Study of flavonoids and phenolic acids in green tea leaves
}

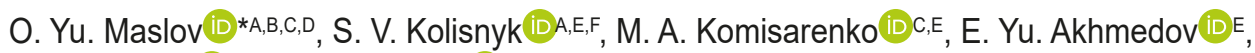 \\ S. M. Poluian ${ }^{\mathbb{E}}$, Z. Z. V. Shovkova $\mathbb{D} E$ \\ National University of Pharmacy, Kharkiv, Ukraine
}

A - research concept and design; B - collection and/or assembly of data; C - data analysis and interpretation; D - writing the article; $\mathrm{E}$ - critical revision of the article; F - final approval of the article

The aim of work is study qualitative composition and quantitative content of flavonoids and phenolic acids in green tea leaves.

Material and methods. The object of the study was green tea leaves, which were collected in Anhui Province, China. The analysis of $60 \%$ ethanolic extract from green tea leaves was performed by high-performance liquid chromatography using a Prominence LC-20 Shimadzu chromatographic system (Japan) with an SPD-20AV spectrophotometric detector, an Agilent Technologies Microsorb-MV-150 column (reversedphase, C18 modified silica gel, length $-250 \mathrm{~mm}$, diameter $-4.6 \mathrm{~mm}$, particles size $-5 \mu \mathrm{m}$ ). Identification of substances in the extract was carried out by comparing the retention time and the spectral characteristics of the test substances with the same characteristics of the reference standards.

Results. 13 compounds were identified and determined by high-performance liquid chromatography. Among flavonoid aglycones quantitatively dominated by quercetin $(0.35 \%)$, in the case of flavonoid glycosides, it was luteolin-6-C-glycoside (1.30 \%) and among phenolic acids, it was gallic acid (5.21\%).

Conclusions. The qualitative composition, quantitative content of flavonoids and phenolic acids in the green tea leaves were determined by high-performance liquid chromatography. According to HPLC, the content of flavonoids in green tea leaves was higher than the content of phenolic acids.

Key words: green tea, leaves, flavonoids, phenolic acids, high-performance liquid chromatography.

Current issues in pharmacy and medicine: science and practice 2021; 14 (3), 287-291

Дослідження фрлавоноїдів і фенолокислот у зеленого чаю листі

О. Ю. Маслов, С. В. Колісник, М. А. Комісаренко, Е. Ю. Ахмедов, С. М. Полуян, З. В. Шовкова

Мета роботи - визначити якісний склад і кількісний уміст фрлавоноїдів і фенолокислот у зеленого чаю листі.

Матеріали та методи. Об'єкт дослідження - зеленого чаю листя, що зібране в провінції Аньхой, КНР. Аналіз 60 \% спиртової витяжки зеленого чаю листя здійснили методом високоефективної рідинної хроматографії за допомогою хроматографічної системи Prominence LC-20 Shimadzu (Японія) зі спектрофотометричним детектором SPD-20AV, колонка Agilent Technologies Microsorb-MV-150 (С18 модифікований силікагель, довжина - 250 мм, діаметр - 4,6 мм, розмір зерен сорбенту - 5 мкм). Ідентифікацію речовин у витяжці виконали шляхом порівняння часу утримування та спектральних характеристик речовин, що досліджували, зі стандартами.

Результати. У зеленого чаю листі ідентифікували 13 сполук, визначили їхній кількісний уміст. Серед агліконів фрлавоноїдів кількісно переважав кверцетин (0,35 \%), а з-поміж глікозидів фрлавоноїдів - лютеолін-6-С-глюкозид (1,30 \%). Із фенольних кислот основна сполука - галова кислота (5,21\%).

Висновки. Встановили якісний склад і кількісний уміст флавоноїдів, фенольних кислот у зеленого чаю листі методом високоефективної рідинної хроматографрії. Вміст фрлавоноїдів у зеленого чаю листі перевищував такий для фенольних кислот.

Ключові слова: зелений чай, листя, фрлавоноїди, фенолокислоти, високоефективна рідинна хроматографія.

Актуальні питання фармацевтичної і медичної науки та практики. 2021. Т. 14, № 3(37). С. 287-291

Исследование флавоноидов и фенолокислот в зелёного чая листьях

А. Ю. Маслов, С. В. Колесник, Н. А. Комиссаренко, Э. Ю. Ахмедов, С. М. Полуян, З. В. Шовковая

Цель работы - определение качественного состава и количественного содержания фрлавоноидов и фенолокислот в зелёного чая листьях.
ARTICLE
UDC 615.322:582.687.21:581.45].07:543.544.5.068.7
INFO DOI: $10.14739 / 2409-2932.2021 .3 .240287$

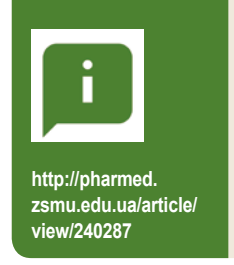
Current issues in pharmacy and medicine: science and practice 2021; 14 (3), 287-291
Key words: green tea, leaves, flavonoids, phenolic acids, high-performance liquid chromatography.
*E-mail: alexmaslov392@gmail.com
Received: 20.09.2021 // Revised: 08.10.2021 // Accepted: 11.10.2021 
Материалы и методы. Объект исследования - зелёного чая листья, собранные в провинции Аньхой, КНР. Анализ 60 \% спиртовой вытяжки зелёного чая листьев провели методом высокоэффективной жидкостной хроматографии с помощью хроматографической системы Prominence LC-20 Shimadzu (Япония) со спектрофотометрическим детектором SPD-20AV, колонка Agilent Technologies Microsorb-MV-150 (С18 модифицированный силикагель, длина - 250 мм, диаметр - 4,6 мм, размер зёрен сорбента - 5 мкм). Вещества в вытяжке идентифицировали путём сравнения времени удерживания и спектральных характеристик исследуемых веществ со стандартами.

Результаты. В зелёного чая листьях идентифицировали 13 соединений, определили их количественное содержание методом высокоэффективной жидкостной хроматографии. Среди агликонов фрлавоноидов количественно преобладал кверцетин (0,35 \%), а из гликозидов флавоноидов - лютеолин-6-С-глюкозид (1,30 \%). Среди феннольных кислот доминирующее соединение - галловая кислота $(5,21 \%)$.

Выводы. Определили качественный состав и количественное содержание фрлавоноидов и фенольных кислот в зелёного чая листьях методом высокоэффективной жидкостной хроматографии. Содержание флавоноидов в зелёного чая листьях превышало содержание френольных кислот.

Ключевые слова: зелёный чай, листья, флавоноиды, фенолокислоты, высокоэффективная жидкостная хроматография.

Актуальные вопросы фрармацевтической и медицинской науки и практики. 2021. Т. 14, № 3(37). С. $287-291$

Tea (Camella sinensis L.) is originated in China, dates back several thousand years. Tea composition varies with climate, season, tea variety, age of the leaf and horticultural practices [1]. A lot of epidemiological and preclinical studies have demonstrated that drinking tea may reduce the risk of cancer and cardiovascular disease $[2,3]$.

Green tea leaves contain numerous bioactive compounds, among which catechins or flavan-3-ols are the most thoroughly investigated. Nevertheless, not only flavan-3-ols are contained in green tea leaves. Tea is rich in aglycones and glycosides of flavanols, flavanones, flavones, and phenolic acids [4,5]. Available scientific studies indicate that seven flavone glycosides were determined in leaves by high-performance liquid chromatography (HPLC), five apigenin compounds (apigenin-6,8-C-diglucoside, apigenin-6-C-glucoside-8-C-arabinoside, apigenin-6-C-arabinoside-8-C-glucoside, apigenin-8-C-glucoside, and apigenin-6-C-glucoside) as well as two luteolin compounds (luteolin-6-C-glucoside and luteolin-8-C-glucoside). In this study, the total amount of flavone glycosides was between $0.48 \mathrm{~g} / \mathrm{kg}$ and $2.69 \mathrm{~g} / \mathrm{kg}[6]$.

Literature shows that flavonols in tea are mainly present in the form of mono-, di-, and triglycosides as well as kaempferol, myricetin, and quercetin have been detected in several studies $[7,8]$. The total content of flavanols can be in the range of $1.0 \%$ to $4.0 \%$ in dry green tea leaves [9]. Moreover, several scientific research have reported about flavanones in the composition of green tea leaves $[10,11]$. Phenolic acids are represented by theogallin, gallic, ferulic, cinnamic acids, as well as the total amount of phenolic acid and its derivatives, which is in the range from $0.1-2.0 \%$ in dry material [12].

\section{Aim}

The aim of the study is determined qualitative composition and quantitative content of flavonoids and phenolic acids in green tea leaves.

\section{Materials and methods}

The object of the study was green tea leaves, which were collected in Anhui Province, China.
Caffeic, gallic, ferulic, cinnamic acids, myricetin-3-O-glycoside, quercetin, quercetin-3-O-rutenoside, naringenin, naringin, hesperidin, hesperetin, luteolin-6-C-glycoside, apigenin-8-C-glycoside were purchased from Sigma-Aldrich. The methanol was HPLC grade and other chemicals were analytical grade.

A Prominence LC-20 Shimadzu liquid chromatography system equipped with a Thermo Scientific Syncronis aQ C18 column $(4.6 \times 250)$ was employed for analyses. All determinations were undertaken at $40^{\circ} \mathrm{C}$. Mobile phases included an aqueous solution of methanol (A) and $1.0 \%$ phosphoric acid solution (B). Gradients of $20-42 \%$ A for $0-15 \mathrm{~min}, 42-43 \%$ A for $15-25 \mathrm{~min}, 43-90 \%$ A for $25-45 \mathrm{~min}$, keeping $90 \%$ A for $45-55 \mathrm{~min}$, decreasing to $20 \%$ A for 55-60 min, and keeping $20 \%$ A for $60-70$ were used. The mobile phases were filtered $(25 \mathrm{~mm} \times 0.45 \mu \mathrm{m}$, Supelco Iso-Disc Filters PTFE 25-4) and degassed prior to use, and a flow rate of $0.5 \mathrm{~mL} /$ min was employed. The sample injection volume was $5 \mu \mathrm{L}$ and the detection was carried out at $255 \mathrm{~nm}, 286 \mathrm{~nm}, 350 \mathrm{~nm}$.

The analysis of plant samples is quite complicated as above all, the plant matrices are often very complex, and identify each substance is impossible, in addition, some standards of substances are very costly. That is why the method of similarity indices was used to provide the analysis. The similarity indices are calculated according to the following formulas [13]:

$$
\begin{aligned}
& \mathrm{I}_{\mathrm{T}}=1-\left|\mathrm{T}_{\mathrm{st}}-\mathrm{T}_{\mathrm{u}}\right| \\
& \mathrm{I}_{255}=1-\left|\mathrm{h}_{255 \mathrm{st}}-\mathrm{h}_{255 \mathrm{u}}\right| \\
& \mathrm{I}_{286}=1-\left|\mathrm{h}_{286 \mathrm{st}}-\mathrm{h}_{286 \mathrm{u}}\right| \\
& \mathrm{I}_{350}=1-\left|\mathrm{h}_{350 \mathrm{st}}-\mathrm{h}_{350 \mathrm{u}}\right|
\end{aligned}
$$

where $\mathrm{I}_{\mathrm{T}}-$ retention time similarity index; $\mathrm{T}_{\mathrm{st}}$ - retention time of standard ( $\mathrm{min}) ; \mathrm{T}_{\mathrm{u}}$ - test substance retention time (min); $\mathrm{I}_{255}, \mathrm{I}_{286}$ and $\mathrm{I}_{350}$ - spectral similarity indices, $\mathrm{h}_{255 \mathrm{st}}$, $\mathrm{h}_{286 \mathrm{st}}$ and $\mathrm{h}_{350 \mathrm{st}}$ - spectral characteristics of the standard; $\mathrm{h}_{255 \mathrm{u}^{\prime}}$, $\mathrm{h}_{286 \mathrm{u}}$ and $\mathrm{h}_{350 \mathrm{u}}-$ spectral characteristics of the test substance.

The spectral characteristic of substance is the ratio of the peak height of chosen wavelength $255 \mathrm{~nm}, 268 \mathrm{~nm}$, and $350 \mathrm{~nm}$ to the peak height of test substance at $225 \mathrm{~nm}$ [14]. For identification analyzed substance the index similarly is chosen among three, which has the lowest value. In order to 
mV

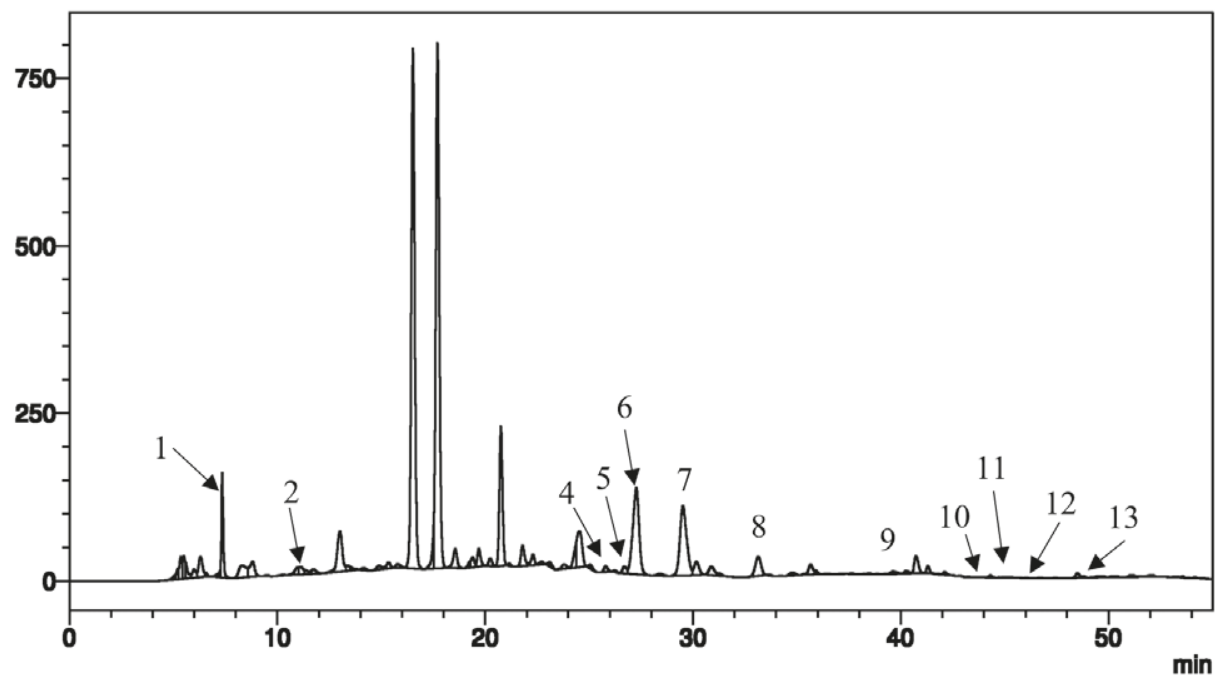

Fig. 1. Chromatogram of test solution of green tea leaves extract, obtained at a wavelength of detection of $255 \mathrm{~nm}$. identify the chromatographic peaks, the value of the similarity index must be greater than 0.7 , if it is not so this peak is unidentified. Some peaks can be outside of the flavonoid range it indicates that this substance is not a flavonoid structure and it can be sorted out to unidentified [15].

Extraction of green tea leaves was made according to the following procedure: $1.0 \mathrm{~g}$ of crushed raw material was extracted by $60 \%$ ethanol in a ratio of 1:20 using method maceration. The resulting extract was filtered through a filter. The raw material was extracted twice with new portions of the solvent, after that the extracts were combined.

Statistical analysis was performed in Microsoft Excel 2010 with the accepted significance level $\alpha=0.05$. Results were expressed as mean \pm confident interval from five measurements.

\section{Results}

The figure shows a chromatogram of green tea extract. Detection of the substance's peaks was provided by a UV detector at a wavelength of $255 \mathrm{~nm} .120$ peaks were identified, which were analyzed by indices of similarity to the standards, 21 peaks were included in the group of unidentified. The chromatogram shows the main peaks, the numbers of which coincide with the numbers of those identified compounds in Table 1. According to the described previously procedure that is based on high similarity indices with standard substances $\mathrm{I}_{\mathrm{T}}$ and $\mathrm{I}_{\mathrm{L}}, 6$ flavonoid glycosides were identified quercetin-3-O-rutenoside, kaempherol-7-O-glycoside, myricetin-3-O-glycoside, hesperidin, luteolin-6-C-glycoside, apigenin-8-C-glycoside as well as 3 flavonoid aglycones quercetin, naringenin, hesperitin (Table 1).

In our research, the number of flavonoid glycosides was: luteolin-6-C-glycoside (1.30\%), hesperidin (1.19\%), apigenin-8-C-glycoside $(0.98 \%)$, myricetin-3-O-glycoside $(0.86 \%)$, quercetin-3-O-rutenoside $(0.62 \%)$, kaempherol-7-O-glycoside $(0.51 \%)$, as well as the total content of flavonoid glycosides in green tea leaves was found $5.46 \%$
Table 1. Identification of substances in the test solution of green tea leaves extract, the peaks of which are indicated in Fig. 1.

\begin{tabular}{|c|c|c|c|}
\hline $\begin{array}{l}\text { Number } \\
\text { of peak } \\
\text { on Fig. } 1\end{array}$ & $\begin{array}{l}\text { Retention } \\
\text { time, min }\end{array}$ & $\begin{array}{l}\text { Similarity } \\
\text { index, IL }\end{array}$ & Identification \\
\hline 1 & 8.815 & 0.826 & gallic acid \\
\hline 2 & 14.850 & 0.921 & hesperidin \\
\hline 3 & 22.295 & 0.816 & apigenin-8-C-glycoside \\
\hline 4 & 24.372 & 0.859 & myricetin-3-O-glycoside \\
\hline 5 & 25.801 & 0.863 & caffeic acid \\
\hline 6 & 27.275 & 0.988 & kaempherol-7-O-glycoside \\
\hline 7 & 29.915 & 0.943 & quercetin-3-O-rutenoside \\
\hline 8 & 33.147 & 0.888 & luteolin-6-C-glycoside \\
\hline 9 & 40.327 & 0.527 & cinnamic acid \\
\hline 10 & 40.727 & 0.760 & quercetin \\
\hline 11 & 40.977 & 0.725 & naringenin \\
\hline 12 & 41.788 & 0.928 & hesperetin \\
\hline 13 & 45.681 & 0.793 & ferulic acid \\
\hline
\end{tabular}

(Table 2). The total amount of flavonoid aglycones and glycosides was $0.41 \%$ and $5.46 \%$, respectively. The phenolic acids were represented by gallic acid (5.21\%), caffeic acid ( $0.16 \%)$, cinnamic acid $(0.02 \%)$, and ferulic acid $(0.01 \%)$. The total content of phenolic acids was $5.39 \%$ in dry raw material.

\section{Discussion}

In scientific research [16] it was estimated that the amount of myricetin-3-O-glycoside was $0.083-0.159 \%$, quercetin-3-O-rutenoside was 0.15-0.48\%, kaempherol-7-O-glycoside was $0.16-0.33 \%$ and quercetin was $0.10-0.50 \%$ in dry material. In this study the content of quercetin-3-O-rutenoside was the greatest. The available research [17] shows 
Table 2. The content of flavonoid glycosides in extract green tea leaves by HPLC-UV

\begin{tabular}{|l|l|}
\hline Glycoside & Content, \% in dry raw material \\
\hline kaempherol-7-O-glycoside & $0.17 \pm 0.01$ \\
\hline quercetin-3-O-rutenoside & $9.35 \pm 0.19$ \\
\hline myricetin-3-O-glycoside & $2.15 \pm 0.04$ \\
\hline apigenin-8-C-glycoside & $2.45 \pm 0.05$ \\
\hline hesperidin & $1.98 \pm 0.04$ \\
\hline luteolin-6-C-glycoside & $3.25 \pm 0.06$ \\
\hline Total flavonoid glycoside & 19.35 \\
\hline &
\end{tabular}

Table 3. The content of flavonoid aglycones in extract green tea leaves by HPLC-UV

\begin{tabular}{|l|l|}
\hline Aglycone & Content, \% in dry raw material \\
\hline quercetin & $0.35 \pm 0.005$ \\
\hline naringenin & $0.02 \pm 0.001$ \\
\hline hesperitin & $0.04 \pm 0.001$ \\
\hline Total flavonoid aglycone & 0.41 \\
\hline
\end{tabular}

Table 4. The content of phenolic acids in extract green tea leaves by HPLC-UV

\begin{tabular}{|l|l|}
\hline Phenolic acid & Content, \% in dry raw material \\
\hline Gallic acid & $5.210 \pm 0.052$ \\
\hline Caffeic acid & $0.160 \pm 0.002$ \\
\hline Cinnamic acid & $0.020 \pm 0.001$ \\
\hline Ferulic acid & $0.010 \pm 0.001$ \\
\hline Total phenolic acids & 5.39 \\
\hline
\end{tabular}

that the content of naringenin was $0.01-0.11 \%$, hesperitin was $0.01-0.07 \%$, hesperidin was $0.31-0.81 \%$. The previous investigation [18] represents the gallic acid was in the range from $2.0 \%$ to $6.0 \%$.

According to results, the luteolin-6-C-glycoside had the highest concentration among other glycosides. The major constituent among aglycones was quercetin, whereas other aglycones were present at the lowest level (Table 3). Obtained results indicated that flavonoid glycosides were predominated in green tea leaves.

The main compound of phenolic acids was gallic acid, the high concentration among others can be explained by the releasing gallic acid from gallaylated catechin-derived species (Table 4). Compared results represent that analyzed green tea leaves are accumulated more flavonoids than phenolic acids.

The differences in results of research can be related with sample preparation method, since different brewing times, ratio leaves/extractant were used, species of tea, climate and geographical position. This work is a contribution for the chemical composition of green tea leaves. Moreover, obtained data can be used further for standardization green tea leaves.

\section{Conclusions}

1. The qualitative composition, quantitative content of flavonoids and phenolic acids green tea leaves were determined by high-performance liquid chromatography.

2. According to HPLC, the content of flavonoids in green tea leaves was higher than the content of phenolic acids.

Prospects for further research. The obtained data on the composition of phenolic acids and flavonoids of green tea leaves will be used for further standardization of the obtained extract and indicate the possibility of creating phytopreparations and food additives on the extract.

Conflicts of interest: authors have no conflict of interest to declare. Конфрлікт інтересів: відсутній.

\section{Information about authors:}

Maslov O. Yu., Assistant of the Department of Analytical Chemistry and Analytical Toxicology, National University of Pharmacy, Kharkiv, Ukraine. ORCID ID: 0000-0001-9256-0934

Kolisnyk S. V., PhD, DSc, Professor, Head of the Department of Analytical Chemistry and Analytical Toxicology, National University of Pharmacy, Kharkiv, Ukraine.

ORCID ID: $\underline{0000-0002-4920-6064}$

Komisarenko M. A., PhD, Assistant of the Department of Pharmacognosy, National University of Pharmacy, Kharkiv, Ukraine.

ORCID ID: 0000-0002-1161-8151

Akhmedov E. Yu., PhD, Associate Professor of the Department of Analytical Chemistry and Analytical Toxicology, National University of Pharmacy, Kharkiv, Ukraine.

ORCID ID: 0000-0001-6727-8259

Poluian S. M., PhD, Associate Professor of the Department of Analytical Chemistry and Analytical Toxicology, National University of Pharmacy, Kharkiv, Ukraine.

ORCID ID: 0000-0002-9942-9258

Shovkova Z. V., PhD, Associate Professor of the Department of Analytical Chemistry and Analytical Toxicology, National University of Pharmacy, Kharkiv, Ukraine.

ORCID ID: 0000-0003-1908-1237

\section{Відомості про авторів:}

Маслов О. Ю., асистент каф. аналітичної хімії та аналітичної токсикології, Національний фрармацевтичний університет, м. Харків, Україна.

Колісник С. В., д-р фарм. наук, профресор, зав. каф. аналітичної хімії та аналітичної токсикології, Національний фармацевтичний університет, м. Харків, Україна.

Комісаренко М. А., канд. фрарм. наук, асистент каф. фрармакогнозії, Національний фрармацевтичний університет, м. Харків, Україна, Ахмедов Е. Ю., канд. фрарм. наук, доцент каф. аналітичної хімії та аналітичної токсикології, Національний фармацевтичний університет, м. Харків, Україна,

Полуян С. М., канд. фарм. наук, доцент каф. аналітичної хімії та аналітичної токсикології, Національний фармацевтичний університет, м. Харків, Україна.

Шовкова 3. В., канд. фрарм. наук, доцент каф. аналітичної хімії та аналітичної токсикології, Національний фрармацевтичний університет, м. Харків, Україна,

\section{Сведения об авторах:}

Маслов А. Ю., ассистент каф. аналитической химии и аналитической токсикологии, Национальный фармацевтический университет, г. Харьков, Украина.

Колесник С. В., д-р фарм. наук, профрессор, зав. каф. аналитической химии и аналитической токсикологии, Национальный фармацевтический университет, г. Харьков, Украина. Комиссаренко Н. А., канд. фрарм. наук, ассистент каф. фрармакогнозии, Национальный фармацевтический университет, г. Харьков, Украина. 
Ахмедов Э. Ю., канд. фрарм. наук, доцент каф. аналитической химии и аналитической токсикологии, Национальный фармацевтический университет, г. Харьков, Украина.

Полуян С. М., канд. фарм. наук, доцент каф. аналитической химии и аналитической токсикологии, Национальный фармацевтический университет, г. Харьков, Украина.

Шовковая 3. В., канд. фарм. наук, доцент каф. аналитической химии и аналитической токсикологии, Национальный фармацевтический университет, г. Харьков, Украина.

References

[1] Jiang, H., Engelhardt, U. H., Thräne, C., Maiwald, B., \& Stark, J. (2015). Determination of flavonol glycosides in green tea, oolong tea and black tea by UHPLC compared to HPLC. Food chemistry, 183, 30-35. https:// doi.org/10.1016/j.foodchem.2015.03.024

[2] Hu, B., Wang, L., Zhou, B., Zhang, X., Sun, Y., Ye, H., Zhao, L., Hu, Q., Wang, G., \& Zeng, X. (2009). Efficient procedure for isolating methylated catechins from green tea and effective simultaneous analysis of ten catechins, three purine alkaloids, and gallic acid in tea by high-performance liquid chromatography with diode array detection. Journal of chromatography. A, 1216(15), 3223-3231. https:// doi.org/10.1016/j.chroma.2009.02.020

[3] Namal Senanayake, S. P. J. (2013). Green tea extract: Chemistry, antioxidant properties and food applications -A review. Journal of Functional Foods, 5(4), 1529-1541. https://doi.org/10.1016/i.jff.2013.08.011

[4] Zhang, L., Cao, Q. Q., Granato, D., Xu, Y. Q., \& Ho, C. T. (2020). Association between chemistry and taste of tea: A review. Trends in Food Science and Technology. Elsevier Ltd. https://doi.org/10.1016/j. tifs.2020.05.015

[5] Farris, P. K. (2013). Cosmeceuticals and Cosmetic Practice. Wiley \& Sons, Incorporated, John: New York.

[6] Engelhardt, U. H. (2013). Reference Module in Chemistry, Molecular Sciences and Chemical Engineering. Elsevier: Amsterdam.

[7] Basaveswara Rao, M. V., Prasanthi, V., Rao, G. V., \& Raman, B. V. (2012). Development and Validation of New RP-HPLC Method for the Determination of Dexrazoxane. Indian journal of pharmaceutical sciences, 74(6), 588-591. https://doi.org/10.4103/0250474X.110627

[8] Jeganathan, B., Punyasiri, P. A., Kottawa-Arachchi, J. D., Ranatunga, M. A., Abeysinghe, I. S., Gunasekare, M. T., \& Bandara, B. M. (2016). Genetic Variation of Flavonols Quercetin, Myricetin, and Kaempferol in the Sri Lankan Tea (Camellia sinensis L.) and Their Health-Promoting Aspects. International journal of food science, 2016, 6057434. https://doi.org/10.1155/2016/6057434

[9] Miean, K. H., \& Mohamed, S. (2001). Flavonoid (myricetin, quercetin, kaempferol, luteolin, and apigenin) content of edible tropical plants. Journal of agricultural and food chemistry, 49(6), 3106-3112. https://doi.org/10.1021/jf000892m

[10] Yashin, A. Y., Nemzer, B. V., Combet, E., \& Yashin, Y. I. (2015). Determination of the Chemical Composition of Tea by Chromatographic Methods: A Review. Journal of Food Research, 4(3), 56. https://doi. org/10.5539/ifr.v4n3p56

[11] Yin, D. D., Yuan, R. Y., Wu, Q., Li, S. S., Shao, S., Xu, Y. J., Hao, X. H., \& Wang, L. S. (2015). Assessment of flavonoids and volatile compounds in tea infusions of water lily flowers and their antioxidant activities. Food Chemistry, 187, 20-28. https://doi.org/10.1016/j. foodchem.2015.04.032

[12] Karamac, M., Kosinska, A., \& Pegg, R. (2006). Content of gallic acid in selected plant extracts. Polish Journal of Food and Nutrition Sciences, 15(1), 55-58.

[13] Khodakov, I. V. (2013). Sposob identifikatsii polifenolov v rastitel'nykh ekstraktakh pri pomoshchi VEZhKh. Opredelenie sostava izoflavonov soi [The HPLC method of identification of polyphenols in plant extracts by example of determination of isoflavone composition in soy seeds]. Metody i ob'ekty khimicheskogo analiza, 8(3), 132-142. [in Russian].

[14] Huat Law, K., \& Patmanatha Das, N. (1987). Dual-wavelength absorbance ratio and spectrum scanning techniques for identification of flavonoids by high-performance liquid chromatography. Journal of Chromatography A, 388(C), 225-233. https://doi.org/10.1016/S00219673(01)94482-6

[15] Sychev, S. N., \& Gavrilina, V. A. (2013). Vysokoeffektivnaya zhidkostnaya khromatografiya. Analitika, fizicheskaya khimiya, raspoznavanie mnogokomponentnykh system [High performance liquid chroma- tography: analytics, physical chemistry, multicomponent system recognition]. Saint-Petersburg: Lan'. [in Russian].

[16] Perva-Uzunalić, A., Škerget, M., Knez, Ž., Weinreich, B., Otto, F., \& Grüner, S. (2006). Extraction of active ingredients from green tea (Camellia sinensis): Extraction efficiency of major catechins and caffeine. Food Chemistry, 96(4), 597-605. https://doi.org/10.1016/j. foodchem.2005.03.015

[17] Zeng, L., Luo, L., Li, H., \& Liu, R. (2017). Phytochemical profiles and antioxidant activity of 27 cultivars of tea. International journal of food sciences and nutrition, 68(5), 525-537. https://doi.org/10.1080/0963 7486.2016.1263834

[18] Jeszka-Skowron, M., Krawczyk, M., \& Zgoła-Grześkowiak, A. (2015). Determination of antioxidant activity, rutin, quercetin, phenolic acids and trace elements in tea infusions: Influence of citric acid addition on extraction of metals. Journal of Food Composition and Analysis, 40, 70-77. https://doi.org/10.1016/i.jfca.2014.12.015 